\title{
Density and reproductive success of Skylarks Alauda arvensis on organic farms - an experiment with unsown Skylark plots on autumn sown cereals
}

\author{
Täthet och häckningsframgång hos sånglärka Alauda arvensis på ekologiska \\ jordbruk - ett experiment med osådda rutor i höstsådd stråsäd
}

ÅKE BERG \& OLLE KVARNBÄCK

\begin{abstract}
Skylark plots (unsown plots; $10-25 \mathrm{~m}^{2}$ per ha) in autumn cereal fields have had positive effects on Skylark density and reproductive success on conventional farms in Britain. We tested if the same effect could be found in organic farms in Sweden by comparing paired fields with and without unsown plots in similar settings. We found that the plots had no effect. Skylark density was only associated (negatively) with field size and not with occurrence of Skylark plots, vegetation structure, yield or weed harrowing. Number of clutches per territory was affected by yield (negative) and vegetation cover (positive) but not by Skylark plots. Number of fledglings per clutch showed negative association with yield and visibility

through the sward. The amount of weed was larger near Skylark plots from the preceding year than in other parts of the field. The yield (and probably vegetation density) was lower on these fields than in conventional autumn sown fields, but still negative effects of the crop (yield levels) were found.

Ake Berg, The Swedish Biodiversity Centre, SLU, Box 7007, SE-750 07 Uppsala. Email: ake.berg@slu.se

Olle Kvarnbäck, Hushållningssällskapet i Stockholm, Uppsala och Södermanlands län, Box 412, SE-751 06 Uppsala
\end{abstract}

\section{Abstract}

Received 12 August 2009, Accepted 20 March 2011, Editor: S. Svensson

\section{Introduction}

The widespread and rapid declines in farmland bird populations in Europe (Tucker \& Heath 1994, Siriwardena et al. 1998, BirdLife International 2004) has been attributed to the intensification of agriculture (Chamberlain et al. 2000, Donald et al. 2001a, Gregory et al. 2005). This includes, for example, simplified crop rotation, more homogeneous and dense crops, loss of semi-natural grassland and non-farmed residual habitats, and increased use of fertilizers and pesticides (Stoate et al. 2001, Robinson \& Sutherland 2002, Newton 2004, Wilson et al. 2005).

Most farmland bird populations have probably declined in numbers due to reduced survival or reproduction caused by factors such as loss and degradation of habitats, food supplies or nest sites (Newton 2004). The Skylark Alauda arvensis is one of the most widespread bird species in European farmland, but it has decreased drastically in numbers during recent decades (BirdLife International 2004, Wretenberg et al. 2006). A probable cause to the decline is lowered reproductive suc- cess due to denser and more homogeneous crops, which are unsuitable for breeding and foraging (Wilson et al. 1997, Chamberlain \& Crick 1999).

The Skylark prefers open habitats and avoids edges with shrubs, woodland or built up areas (Piha et al. 2003, Donald 2004), probably due to an increased nest predation risk near these structures (Møller 1989, Andrén 1995). Skylarks are found in high densities on seminatural grasslands and set-asides (Berg \& Pärt 1994, Poulsen et al. 1998, Chamberlain et al. 2000, Donald et al. 2001b, Henderson et al. 2000, Toepfer \& Stubbe 2001, Eraud \& Boutin 2002) and prefer an intermediate vegetation height $(15-60 \mathrm{~cm})$. The preferred vegetation height varies between studies (Wilson et al. 1997, Chamberlain et al. 1999, Donald et al. 2001b, Toepfer \& Stubbe 2001, Eraud \& Boutin 2002), probably due to differences in vegetation structure and vegetation cover. The reproductive success has been shown to be high on set-asides in some studies (Wilson et al. 1997, Poulsen et al. 1998). However, other studies have found a higher reproductive success on cereal crops than on setasides (Donald et al. 2002). A probable reason is 
differences in management, vegetation structure and vegetation height on different types of fields in different areas (Donald et al. 2002).

In general, the density of Skylarks has been shown to be higher on organic farms than on conventional farms (Wilson et al. 1997, Kragten et al. 2008). However, some aspects of organic farming (i.e. cutting of organic set asides during the breeding season; see Berg et al. 2009) have negative impacts on reproductive success. Establishment of unsown patches (hereafter called Skylark plots) have been shown to increase density and reproductive success on conventional farms (Morris et al. 2004). The effects of Skylark plots have not been investigated on organic arable crops.

The aim of this study was to evaluate the effects of Skylark plots on organic autumn sown cereal crops. Density and reproductive success of Skylarks were compared on pairs of autumn sown fields with and without Skylark plots. Effects of different vegetation variables (height, cover, density and yield), field size and weed harrowing were also evaluated. Furthermore, abundance of weeds on areas with Skylark plots in the preceding year was studied on a subset of fields.

\section{Methods}

\section{Study sites}

A total of 30 organic autumn sown fields (18 fields in 2007 and 12 new fields in 2008, mean area \pm S.D. $=12.4 \pm 4.7 \mathrm{ha}$ ) were included in the study. The main study area was in the county of Uppland, within $50 \mathrm{~km}$ from Uppsala (approximate location $59^{\circ} 56^{\prime} \mathrm{N}, 17^{\circ} 38^{\prime} \mathrm{E}$ ). Two fields south of Stockholm and two fields in southernmost Sweden (Tomelilla in Skåne) were also included in the study. Fields situated in open landscapes were selected since Skylarks avoid areas close to forest edges (Piha et al. 2003, Donald 2004). The study included 15 fields with and 15 fields without Skylark plots. These 30 fields were located pair-wise, in the same or in two neighbouring farms at least $100 \mathrm{~m}$ from each other and in similar surrounding landscapes. The selection of fields used as control and as experimental fields (with Skylark plots) was random, but in a few cases the farmer decided this due to practical reasons.

Most Skylark plots ( $\mathrm{n}=11$ fields) were established during autumn at sowing. Plots (10-25 $\left.\mathrm{m}^{2}\right)$ at a distance of 60-70 $\mathrm{m}$ from each other (two plots per ha) were not sown. In two cases the plots were improved by harrowing during the spring. In four cases the plots were established during spring
(April) by harrowing of the sown crop. The plots were not managed, but some fields (eight fields with and four fields without Skylark plots) were harrowed for weeds in April-May.

\section{Bird censuses and estimates of reproductive success}

The selected fields were searched for Skylarks with territory mapping (Bibby et al. 1992). Each field was visited 6 times between 25 April and 24 May. Territories were searched for signs of successful reproduction at 3-4 occasions between 25 May and 26 July. Parts of adjacent fields $(<50 \mathrm{~m})$ were also included to avoid biases due to movements of broods from bordering fields into the investigated fields. Only territories with a majority of the observations within the field were included in density estimates, which were based on the area of the set-aside field. (i.e. adjacent censused areas were not included). The observer walked through the fields along transects with 10-15 m intervals and all observed young were recorded on maps and assigned to the territory within which the observation was done. We estimate that problems with assigning broods to wrong territories (due to movements of broods) were relatively small due to the poor reproductive success and distances between broods (many pairs failed). Two measures were used to estimate reproductive success, i.e. the number of fledged broods per territory, and the number of fledglings per brood, both averaged at the field level.

\section{Vegetation variables}

Vegetation height, cover and density were estimated at five random points on each field during July. Vegetation cover was estimated in plots $\left(1 \mathrm{~m}^{2}\right)$ by ocular estimation. Vegetation cover was classified in the following classes: $0-2 \%=1,2-10 \%=6$, $11-20 \%=15,21-30 \%=25,31-40 \%=35$ etc. up to $100 \%$. Visibility $(\mathrm{m})$ along seed furrows was estimated as the distance at which $>50 \%$ of the ground was visible. Visibility (m) perpendicular to seed furrows was estimated in the same way. Vegetation height was estimated as the mean height of the crop spikes. The farmers reported the yield $(\mathrm{kg} / \mathrm{ha})$ from each field.

Six of the fields with Skylark plots in 2007 were mapped for weeds during 2008. Six Skylark plots were selected on each field. A metal frame $(0.25$ $\mathrm{m}^{2}$ ) was positioned in each corner (one metre from the plot border to avoid edge effects) of the Skylark plot. The small plots were mapped for differ- 
ent weeds in June (all weeds were cut with a scissor and the fresh weight was measured for different weed taxa). For comparison six control plots of the same size, situated adjacent to the Skylark plots, were mapped for weeds with the same methods.

\section{Analyses}

All vegetation variables (vegetation height, vegetation cover, and visibility along or perpendicular to seed furrows) were square root transformed. Density of Skylarks and number of clutches per territory was first compared with pair-wise t-tests without including other environmental variables. Density and reproductive success (number of clutches per territory and number of fledglings per clutch) on fields with and without Skylark plots were also analysed with models (ANCOVA, regression analyses) including different combinations of vegetation variables, field size and weed harrowing. The analyses were performed with backward selection of covariables (vegetation variables) and two factors (occurrence of Skylark plots and weed harrowing).

Two values for weed fresh weights were calculated for each field, i.e. mean values (for different weed taxa) from six plots within and six plots outside Skylark plots were used in these pair-wise comparisons. Occurrences of different weeds (fresh weight) were analysed with pair-wise nonparametric tests (Wilcoxon signed ranks tests) due to the skewed distributions.

\section{Results}

\section{Skylark density}

The density of Skylarks on fields with Skylark plots (mean $\pm \mathrm{se}=0.76 \pm 0.06$ territories/ha) and on fields without Skylark plots (mean $\pm \mathrm{se}=0.77 \pm 0.09$ territories/ha) did not differ significantly (pair-wise t-test, $\mathrm{t}=0.06, \mathrm{p}>0.9$ ).

The density of Skylarks on fields with and without Skylark plots was also analysed with models including different vegetation variables. The analyses were initiated with a model that included field size, all vegetation variables, yield and two factors (occurrence of Skylark plots and weed harrowing during the breeding season). Not significant variables were removed in a backward selection

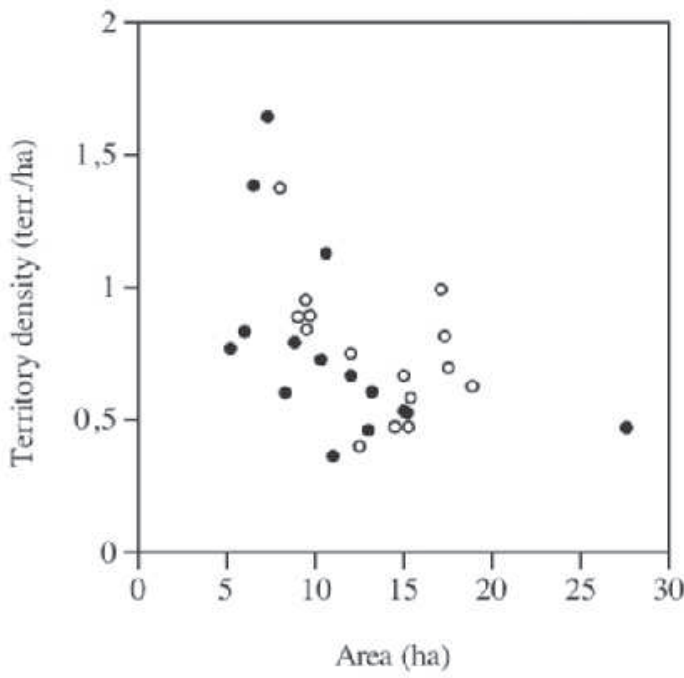

Figure 1. Relationship between territory density (territory/ ha) and area (ha). Open circles represent fields without Skylark plots and filled circles represent fields with Skylark plots.

Förhållandet mellan revirtäthet (revir/ha) och areal (ha). Öppna ringar representerar fält utan sånglärkerutor och fyllda ringar fält med sånglärkerutor.

Table 1. Density of Skylarks, vegetation height, vegetation cover, visibility (along and perpendicular to seed furrows) and yield on fields with and without Skylark plots.

Sånglärketäthet, vegetationens höjd och täckningsgrad, sikt längs och tvärs såraderna samt avkastning för fält med och utan sånglärkerutor.

\begin{tabular}{lcc}
\hline & & \multicolumn{2}{c}{ Mean Medelvärde \pm SE } \\
\cline { 2 - 3 } Variable & $\begin{array}{c}\text { Fields with plots } \\
\text { Fält med lärkrutor } \\
(\mathrm{n}=15)\end{array}$ & $\begin{array}{c}\text { Fields without plots } \\
\text { Fält utan lärkrutor } \\
(\mathrm{n}=15)\end{array}$ \\
\hline Skylark density (terr./ha) Revir/ha & $0.77 \pm 0.09$ & $0.76 \pm 0.06$ \\
Vegetation height Stråhöjd $(\mathrm{cm})$ & $78.1 \pm 4.3$ & $81.4 \pm 6.2$ \\
Vegetation cover Täckningsgrad (\%) & $61.8 \pm 4.3$ & $62.9 \pm 4.0$ \\
Visibility perpendicular to seed furrows Sikt tvärs såraderna $(\mathrm{m})$ & $2.0 \pm 0.2$ & $2.3 \pm 0.4$ \\
Visibility along seed furrows Sikt längs såraderna $(\mathrm{m})$ & $4.5 \pm 0.7$ & $3.8 \pm 0.5$ \\
Yield Avkastning $(\mathrm{kg} /$ ha) & $4267 \pm 322$ & $3793 \pm 162$ \\
\hline
\end{tabular}


Table 2. Results from a regression analysis $(\mathrm{F}=8.2$, $\mathrm{df}=2, \mathrm{R}^{2}=0.38$ ), $\mathrm{p}=0.002$ ) with number of clutches per territory as dependent variable and yield and vegetation cover as independent variables.

Resultat $a v$ en regressionsanalys $(F=8,2, \quad d f=2$, $\left.\left.R^{2}=0,38\right), p=0,002\right)$ med antal kullar per revir som beroende variabel och avkastning och som oberoende variabler.

\begin{tabular}{lcc}
\hline Variable & t-value & p-value \\
\hline Yield Avkastning & -4.0 & $<0.001$ \\
Vegetation cover Täckning & 3.2 & $<0.01$ \\
\hline
\end{tabular}

Table 3. Results from a regression analysis $(\mathrm{F}=7.5$, $\mathrm{df}=2, \mathrm{R}^{2}=0.36$ ), $\mathrm{p}=0.003$ ) with number of fledglings per clutch as dependent variable and yield and visibility perpendicular to seed furrows as independent variables.

Resultat frain en regressionsanalys $(F=7,5, d f=2$, $\left.\left.R^{2}=0,36\right), p=0,003\right)$ med antal flygga ungar per kull som beroende variable och avkastning och sikt tvärs såraderna som oberoende variabler.

\begin{tabular}{lcc}
\hline Variable & $\mathrm{t}$-value & $\mathrm{p}$ - value \\
\hline Yield Avkastning & -3.8 & 0.001 \\
Visibility perpendicular to seed & & \\
furrows Sikt tvärs såraderna & -2.7 & $<0.05$ \\
\hline
\end{tabular}

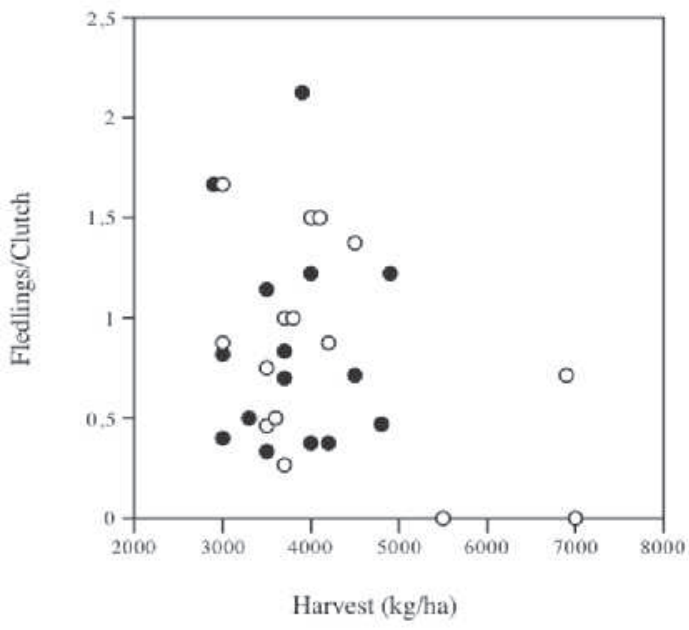

Figure 2. Relationship between number of skylark fledglings per brood and yield (kg/ha) on 30 autumn sown fields. Open circles represent fields without skylark plots and filled circles represent fields with skylark plots.

Förhållandet mellan antal flygga ungar per kull och avkastning (kg/ha) för 30 höstsådda fält. Öppna ringar representerar fält utan sånglärkerutor och fyllda ringar fält med sånglärkerutor. process. In the final model field size was the only variable that was significantly (negatively) associated to Skylark density $(\mathrm{F}=9.2, \mathrm{df}=1, \mathrm{p}=0.005)$, see Figure 1. Thus, density of Skylarks was not associated with occurrence of Skylark plots, vegetation variables or yield (Table 1).

\section{Reproductive success}

Number of clutches per territory did not differ between fields with (mean $\pm \mathrm{se}=0.57 \pm 0.05)$ and without (mean $\pm \mathrm{se}=0.49 \pm 0.07$ ) Skylark plots (pair wise $\mathrm{t}$-test, $\mathrm{t}=0.09, \mathrm{p}>0.9$ ). Similarly, number of fledglings per clutch did not differ between fields with (mean $\pm \mathrm{se}=1.41 \pm 0.11$ ) and without (mean $\pm \mathrm{se}=1.43 \pm 0.18$ ) Skylark plots (pair wise t-test, $\mathrm{t}=$ $0.09, \mathrm{p}>0.9$ ).

The reproductive success was also analysed with models including field area, vegetation variables and density of Skylarks. The analyses were initiated with a model that included field size, all vegetation variables, yield and two factors (occurrence of Skylark plots and weed cutting during the breeding season). Not significant variables were removed in a backward selection process. The final model for number of clutches per territory included significant effects of yield (negative) and vegetation cover (positive), see Table 2, but no effect of Skylark plots.

Models with number of fledglings per clutch as dependent variable showed negative associations with yield and visibility perpendicular to seed furrows (Table 3).

\section{Weed occurrence}

Analyses of weed occurrence in 2008 showed that there were some negative effects of the Skylark plots in 2007. Analyses of weed weight showed that amount of grasses and the total amount of weeds (all species pooled) were larger in areas where Skylark plots occurred in the preceding year than in the rest of the field (Table 4).

\section{Discussion}

There was a negative relationship between Skylark density and field size (Figure 1) in this study. In general, Skylarks prefer large open fields (Piha et al. 2003, Donald 2004), so this relationship was somewhat unexpected. However, Skylarks mainly avoid forest edges, vicinity to farm buildings and other high structures. Therefore fields with such structures close to the field edge were not included 
Table 4. Occurrence of different weeds 2008 (mean weight \pm SD) on fields with and without Skylarks plots in 2007. Z-values and p-values from Wilcoxon signed ranks tests.

Förekomst av olika ogräs 2008 (medelvikt $\pm S D$ ) på fält med och utan sånglärkerutor 2007. Z-värden och pvärden från Wilcoxon test.

\begin{tabular}{|c|c|c|c|c|c|c|}
\hline \multirow[t]{2}{*}{$\begin{array}{l}\text { Weed taxa } \\
\text { Ogrässläkte }\end{array}$} & \multicolumn{2}{|c|}{$\begin{array}{l}\text { Weight within plots } \\
\text { Vikt inom rutor }\end{array}$} & \multicolumn{2}{|c|}{$\begin{array}{l}\text { Weight outside plots } \\
\text { Vikt utanför rutor }\end{array}$} & \multirow{2}{*}{\multicolumn{2}{|c|}{$\begin{array}{c}\mathrm{Z} \text { - } \\
\text { value } \mathrm{p} \text {-value }\end{array}$}} \\
\hline & Mean & S.D. & Mean & S.D. & & \\
\hline Galeopsis & 2.4 & 5.8 & 1.6 & 3.8 & -1 & $>0.3$ \\
\hline Poace & 2.6 & 4.5 & 16.6 & 19.6 & -2 & $<0.05$ \\
\hline Fumaria & 0.0 & 0.0 & 1.5 & 3.7 & -1 & $>0.3$ \\
\hline Taraxacum & 0.1 & 0.3 & 3.3 & 5.2 & -1.3 & $>0.1$ \\
\hline Sonchus & 0.0 & 0.0 & 2.3 & 4.0 & -1.3 & $>0.1$ \\
\hline Thlaspi & 1.5 & 3.7 & 0.1 & 0.3 & -1.3 & $>0.1$ \\
\hline Lamium & 1.2 & 3.0 & 1.5 & 3.7 & -1 & $>0.3$ \\
\hline Brassica & 0.8 & 2.0 & 4.1 & 10.1 & -1 & $>0.3$ \\
\hline Galium & 4.3 & 7.3 & 4.7 & 7.0 & -1 & $>0.2$ \\
\hline Chenopodium & 6.7 & 16.3 & 7.6 & 18.5 & -1 & $>0.3$ \\
\hline Cirsium & 144.0 & 234.8 & 209.4 & 311.7 & -1.5 & $>0.1$ \\
\hline Equisetum & 0.8 & 2.0 & 0.0 & 0.0 & -1 & $>0.3$ \\
\hline Total & 164.5 & 232.2 & 252.7 & 301.5 & -2.2 & $<0.05$ \\
\hline
\end{tabular}

in this study. Earlier studies have shown that Skylarks might prefer heterogeneous landscapes with different crops and field edges (Chamberlain \& Gregory 1999, Chamberlain et al. 1999), although some studies have shown that nest predation rates can be elevated also near open field edges (Donald 2004, Morris \& Gilroy 2006). A large proportion $(50 \%)$ of the territories in this study were situated at the border between two crops, possibly due to availability of both foraging habitats and nesting habitats within the territory. Furthermore, heterogeneous habitats have areas suitable for nesting during different times in the season (Schläpfer 1988, Jenny 1990, Wilson et al. 1997, Chamberlain \& Gregory 1999, Chamberlain et al. 1999), and renesting after breeding failures might be more common in heterogeneous landscapes.

The Skylark plots were established in order to create a mosaic of vegetation patches of low vegetation suitable for foraging, especially late in the season when the crops are tall and dense. However, no effects of the Skylark plots on density or reproduction could be detected in this study. A possible cause to this is that the density of the crops on the investigated organic fields was not dense enough to cause trouble for the breeding Skylarks. This is indicated by the analyses of reproductive success, which showed that the number of fledglings per clutch (Figure 2) was negatively affected by yield, especially at yields over five tons per ha (Figure 2). Only three of the investigated fields had such high yields, which can be compared to a mean yield of 6.4 tons per ha on conventional farms in the region 2007 (Statistics Sweden 2008). Skylarks plots have been shown to have positive effects on breeding density, length of breeding season and reproductive success on conventional cereal crops in Britain (Morris et al. 2004), although the plots does not seem to increase invertebrate numbers at the field level (Smith et al. 2009). A probable mechanism for the improved conditions is increased availability of food in the sparse vegetation in the Skylark plots (Morris 2004).

Thus, the organic autumn-sown cereal crops in this study were attractive habitats for Skylarks with high densities of territories (mean density = 0.76 territories per ha), somewhat lower than on stubble fields and permanent set-asides (Kvarnbäck et al. 2006, Berg \& Pärt 2004) and higher than on spring-sown cereals. However, the overall reproductive success was low (mean $=0.85$ fledglings per pair) compared to the two fledglings per pair that is calculated to be needed for maintaining a stable population (Kvarnbäck 2009). Reproductive success was negatively related to yield and strongly affected by vegetation density (measured as visibility, cover or harvest) on a few fields with harvests over 5 tons per ha. Weed harrowing did not affect reproductive success in this study, which it usually does. Nest predation might have strong effects on the reproductive success of Skylarks (Donald 2004), especially close to field 
edges (Morris et al. 2006), but this was not evaluated in our study.

The overall weed occurrence was higher in areas with Skylark plots in the preceding year than on other parts of the field (Table 4). However, the difference was only significant for the total amount of weeds and for grasses (Table 4). In addition, the Skylark plots made up a small part of the field area $(<0.5 \%)$ and therefore the overall increase in weed abundance on the field level was small.

To conclude, Skylark plots did not have positive effects on reproductive success or densities of Skylarks on organic autumn sown cereal crops. The harvest (and probably vegetation density) was lower on these fields than on conventional autumn sown fields, but some negative effects of the crop (harvest levels) were found. Skylark plots are cheap to implement (50 SEK per ha, see Kvarnbäck 2009), are accepted by the farmers, and give rise to only moderate weed increase. Therefore, the method should be evaluated further on fields with higher harvests and denser vegetation than organic autumn sown cereals.

\section{Acknowledgements}

The Swedish Board of Agriculture funded this study (to OK). Many thanks to all the farmers that were involved in the study and to the field assistants that censused birds and mapped habitats.

\section{References}

Andrén H. 1995. Effects of habitat edge and patch size on bird-nest predation. In Mosaic landscapes and ecological processes (Hansson, L, Fahrig, L. \& Merriam, G., eds.). Chapman, Hall, London.

Berg, Å. \& Pärt, T. 1994. Abundance of farmland birds on arable and set-aside fields at forest edges. Ecography 17: 147-152.

Berg, Å., Kvarnbäck, O. \& Gustafsson, Å. 2009. Breeding skylarks Alauda arvensis on organic set-asides - effects of time of cutting, landscape composition and vegetation structure. Ornis Svecica 19: 32-40.

Bibby, C.J., Burgess, D. \& Hill, D.A. 1992. Bird Census Techniques. Academic Press, London.

BirdLife International. 2004. Birds in Europe: population estimates, trends and conservation status. BirdLife International. (BirdLife Conservation Series No. 12), Cambridge.

Chamberlain, D.E. \& Crick, H.Q.P. 1999. Population declines and reproductive performance of Skylarks Alauda arvensis in different regions and habitats of the United Kingdom. Ibis 141: 38-51.

Chamberlain, D. E. \& Gregory, R. D. 1999. Coarse and fine scale habitat associations of breeding skylarks Alauda arvensis in the UK. Bird Study 46: 34-47.
Chamberlain, D. E., Wilson, A.M., Browne, S. J. \& Vickery, J. A. 1999. Effects of type and management on the abundance of skylarks in the breeding season. Journal of Applied Ecology 36: 856-870.

Chamberlain, D.E., Fuller, R.J., Bunce, R.G.H., Duckworth, J.C. \& Shrubb, M. 2000. Changes in the abundance of farmland birds in relation to timing of agricultural intensification in England and Wales. J. Appl. Ecol. 37: 771-788.

Donald, P. 2004. The Skylark. Poyser, London.

Donald, P.F., Green, R.E. \& Heath, M.F. 2001a. Agricultural intensification and the collapse of Europe's farmland bird populations. Proceedings of the Royal Society of London Series B-Biological Sciences: 268: 25-29.

Donald, P.F., Evans, A.D., Buckingham, D.L., Muirhead, L.B. \& Wilson, J.D. 2001b. Factors affecting the territory distribution of Skylarks Alauda arvensis breeding on lowland farmland. Bird Study 48: 271-278.

Donald, P.F., Evans, A.D., Muirhead, L.B., Buckingham, D.L., Kirby, W.B. \& Schmitt, S.I.A. 2002. Survival rates, causes of failure and productivity of skylarks Alauda arvensis nests on lowland farmland. Ibis 144: 652-664.

Eraud, C. \& Boutin, J.M. 2002. Density and productivity of breeding skylarks Alauda arvensis in relation to crop type on agricultural lands in western France. Bird Study 49: 287-296.

Gregory, R.D., van Strien, A., Vorisek, P., Meyling, A.W.G., Noble, D.G., Foppen, R.P.B. \& Gibbons, D.W. 2005. Developing indicators for European birds. Philosophical Transactions of The Royal Society B-Biological Sciences 360: 269-288.

Henderson, I.G., Cooper, J., Fuller, R.J. \& Vickery, J. 2000. The relative abundance of birds on set-asides and neighbouring fields in summer. J. Appl. Ecol. 37: 335-347.

Jenny, M. 1990. Territorialität und Brutbiologie der feldlerche Alauda arvensis in einer intensiv genutzen Agrarlandschaft. Journal für Ornithologie 131: 241-265.

Kragten, S., Trimbos, K.J. \& de Snoo, G.R. 2008. Breeding skylarks (Alauda arvensis) on organic and conventional arable farms in The Netherlands. Agriculture, Ecosystems and Environment 126: 163-167.

Kvarnbäck, O., Eriksson, S. \& Pettersson, M.W. 2006. Sånglärkor på trädor - en fältundersökning av häckning i östra Mellansverige och kopplingen till vegetation och putsningsstrategier. Rapport 5536. Naturvårdsverket, Stockholm.

Kvarnbäck, O. 2009. Förbättrad överlevnad av fågelungar på ekologiska fält - försök med lärkrutor och kantzoner. Rapport Hushållningssällskapet.

Morris, A.J. \& Gilroy, J.J. 2006. Close to the edge: predation risks for two declining farmland passerines. Ibis 150: 168-177.

Morris, A.J., Holland, J.H., Smith, B. \& Jones, N.E. 2004. Sustainable farming for an improved environment (SAFFIE): managing winter wheat sward structure for skylarks Alauda arvensis. Ibis 146 (suppl): 155-162.

Møller, A.P. 1989. Nest site selection across field-woodland ecotones: the effect of nest predation. Oikos 53: 215-221.

Newton, I. 2004. The recent declines of farmland bird populations in Britain: an appraisal of causal factors and conservation actions. Ibis 146: 579-600.

Piha, M., Pakkala, T. \& Tiainen, J. 2003. Habitat preferences of the Skylark in southern Finland. Orn. Fenn. 80: 97-110. 
Poulsen, J.G., Sotherton, N.W. \& Aebischer, N.J. 1998. Comparative nesting and feeding ecology of Skylarks Alauda arvensis on arable farmland in southern England with special reference to set-aside. J. Appl. Ecol. 35: 131-147.

Robinson, R.A. \& Sutherland, W.J. 2002. Post-war changes in arable farming and biodiversity in Great Britain. $J$. Appl. Ecol. 39: 157-176.

Schläpfer, A. 1988. Populationsökologie der Feldlerche Alauda arvensis in der intensiv genutzen Agrarlandschaft. Der Ornitologische Beobachter 85: 305-371.

Siriwardena, G.M., Baillie, S.R., Buckland, S.T., Fewster, R.M., Marchant, J.H. \& Wilson, J.D. 1998. Trends in the abundance of farmland birds: a quantitative comparison of smoothed Common Birds Census indices. J. Appl. Ecol 35: 24-43.

Smith, B., Holland, J, Jones, N., Moreby, S. Morris. A.J. \& Southway, S. 2009. Enhancing invertebrate food resources for skylarks in cereal ecosystems: how useful are incrop agri-environmental scheme management options? $J$. Appl. Ecol. 46: 692-702.

Statistics Sweden. 2008. Production of organic and nonorganic farming 2007. Jo 16 SM 0802.

Stoate, C., Boatman, N.D., Borralho, R.J., Carvalho, C.R., de Snoo, G.R. \& Eden, P. 2001. Ecological impacts of arable intensification in Europe. Journal of Environmental Management 63: 337-365.

Toepfer, S. \& Stubbe, M. 2001. Territory density of the Skylark (Alauda arvensis) in relation to field vegetation in central Germany. Journal für Ornithologie 142: 184-194.

Tucker, G.M. \& Heath, M.F. 1994. Birds in Europe. Their conservation status. Birdlife Conservation series no. 3. Birdlife International, Cambridge.

Wilson, J.D., Evans, J., Browne, S.J. \& King, J.R. 1997. Territory distribution and breeding success of skylarks Alauda arvensis on organic and intensive farmland in southern England. J. Appl. Ecol 34: 1462-1478.

Wilson, J.D., Whittingham, M.J. \& Bradbury, R.B. 2005. The management of crop structure: a general approach to reversing the impacts of agricultural intensification on birds? Ibis 147: 453-463.

Wretenberg, J., Lindström, Å., Svensson, S., Thierfelder, T. \& Pärt, T. 2006. Population trends of farmland birds in Sweden and England - similar trends but different patterns of agricultural intensification. J. Appl. Ecol. 43: $1110-1120$.

\section{Sammanfattning}

Syftet med denna undersökning var att utvärdera effekter av sånglärkerutor (två osådda $10-25 \mathrm{~m}^{2}$ stora rutor per ha) och vegetationstruktur på ekologiska fält med höstsådd säd. Tätheten av sånglärka var negativt korrelerad med fältets storlek, men inte med olika vegetationsvariabler eller ogräsharvning. Antal kullar per revir var negativt korrelerad till skörd och positivt korrelerad till vegetationens täckningsgrad. Antal ungar per kull var negativt korrelerad till skörd och till sikt (mot såraden). Analyser av ogräsförekomsten 2008 visade att den totala mängden ogräs och mängden gräs (friskvikter) var större på områden där sånglärkerutor legat året innan än på resterande delar av fältet. Skörden på de ekologiska fälten var betydligt lägre än på konventionellt odlade fält, vilket kan vara en orsak till att ingen effekt av sånglärkerutorna kunde påvisas, även om häckningsframgången var negativt korrelerad till skördens storlek. Sånglärkerutor är billiga att anlägga, accepteras av lantbrukare, ger inte upphov till stora ogräsproblem, metoden bör därför undersökas också på konventionellt odlade fält.

\section{Metoder}

30 fält med ekologiskt odlad höstsådd ingick i denna studie (18 fält under 2007 och 12 nya fält under 2008). Huvudundersökningsområdet låg i Uppland, inom $50 \mathrm{~km}$ från Uppsala. Två fält söder om Stockholm och två fält i Skåne (Tomelilla) ingick också i undersökningen. Fälten var parvis belägna (på samma eller närbelägna gårdar) i liknande landskap (öppna landskap utan skogskanter), minst $100 \mathrm{~m}$ från varandra. På $15 \mathrm{av}$ fälten anlades sånglärkerutor (10-25 $\mathrm{m}^{2}$ stora, två per ha) och 15 fält var kontroller utan sånglärkerutor. De flesta rutorna $(\mathrm{n}=11)$ anlades vid sådden på hösten, men på fyra fält anlades rutorna genom harvning på våren. Ogräsharvning under våren (april-maj) skedde på åtta av fälten med sånglärkerutor och fyra av fälten utan sånglärkerutor.

Revirkartering av sånglärkor skedde på fälten under 6 besök under perioden 25 april-24 maj. Därefter genomsöktes fälten vid 3-4 tillfällen för att hitta ungkullar. Inventeraren genomsökte fälten genom att gå längs transekter med 10-15 meters intervall och alla observerade ungar noterades på kartor. Dessa data sammanställdes till antal kullar per revir och antal flygga ungar per kull för varje fält.

Under 2008 karterades ogräsförekomsten på sex av fälten med sånglärkerutor 2007. En metallram $\left(0,25 \mathrm{~m}^{2}\right)$ placerades i varje hörn av 6 sånglärkerutor (1 m från kanten för att undvika kanteffekter) och på samma sätt i sex intilliggande kontrollrutor. Under juni månad så karterades förekomsten av olika ogräs och dessa klipptes av och vägdes (friskvikt).

\section{Resultat}

Tätheten av sånglärka var negativt korrelerad till fältstorleken (Figur 1), men det fanns ingen signifikant effekt av sånglärkerutor, olika vegetationsva- 
riabler eller ogräsharvning. Antal kullar per revir var negativt korrelerad till fältets skörd och positivt korrelerad till vegetationens täckningsgrad (Tabell 2), men det fanns ingen effekt av sånglärkerutor eller ogräsharvning. Antal flygga ungar per kull var också negativt korrelerad till fältets skörd samt till sikt tvärs mot sårader (Tabell 3, Figur 2). Analyserna av ogräsförekomst visade att det fanns signifikant mer gräs och total mängd ogräs (friskvikt) på de delar av fältet där det fanns sånglärkerutor föregående år.

\section{Diskussion}

De undersökta höstsådda fälten hade höga tätheter av sånglärka ( 0,76 revir per ha), vilket är något lägre än prefererade habitat som stubbåkrar och trädor. Det fanns ingen effekt av de anlagda sånglärkerutorna på tätheten av sånglärka. Tätheten var högre på mindre fält, vilket kan bero på att sånglärkan föredrar heterogena landskap med olika grödor och kantzoner, även om vissa studier visat att bopredationsrisken kan vara hög nära kantzoner. Heterogena landskap kan också erbjuda fält som är lämpliga häckningsbiotoper under olika delar av säsongen. Generellt var häckningsframgången låg på de undersökta fälten $(0,85$ flygga ungar per kull), vilket kan jämföras med de två ungar per kull som vi funnit behövs för att behålla en stabil population. Häckningsframgången (både antal kullar per revir och antal flygga ungar per kull) var negativt korrelerad till skörden på de olika fälten, men påverkades inte av förekomsten av sånglärkerutor eller ogräsharvning. Bopredation kan vara en faktor som har stor effekt på häckningsframgången, speciellt nära kanter (där många revir fanns), men detta utvärderads inte i vår undersökning.

Förekomsten av ogräs (total förekomst och förekomst av gräs) var högre i de områden där sånglärkerutor fanns året innan än på övriga delar av fältet. Sånglärkerutorna utgjorde en begränsad del $(<0,5 \%)$ av fältets yta, så den negativa effekten av ogräs får anses vara mycket begränsad.

Sammanfattningsvis visade denna undersökning ingen effekt av anlagda sånglärkerutor på täthet eller häckningsframgång hos sånglärka. Skördenivån på de ekologiska fälten är betydligt lägre än på konventionellt odlade fält (Statistics Sweden 2008). Sånglärkerutor är billiga att anlägga (ca 50 $\mathrm{kr}$ per ha), accepteras av de flesta lantbrukare, ger begränsade ogräsproblem och metoden bör därför prövas i större skal på konventionellt odlade fält med tätare grödor. 